DOI

\title{
ОСОБЛИВОСТІ КОМУНІКАТИВНОГО СТИЛЮ ВИКЛАДАЧІВ ДИСЦИПЛІН РІЗНИХ НАВЧАЛЬНИХ БЛОКІВ У КОНТЕКСТІ СТУДЕНТОЦЕНТРОВАНОГО ПІДХОДУ
}

\author{
В. М. Лісовий, В. А. Капустник, В. Д. Марковський, І. В. Завгородній, \\ В. М. Сінайко, К. В. Дмитрієнко, О. А. Мирончук \\ Харківський національний медичний університет

\section{CHARACTERISTICS OF COMMUNICATIVE STYLE OF TEACHERS OF THE DIFFERENT EDUCATIONAL BLOCKS IN THE STUDENT- CENTERED APPROACH}

\author{
V. M. Lisovyi, V. A. Kapustnyk, V. D. Markovskyi, I. V. Zavhorodnii, V. M. Sinayko, \\ K. V. Dmytriyenko, O. A. Myronchuk \\ Kharkiv National Medical University
}

\begin{abstract}
У статті представлені результати дослідження особливостей реалізації студентоцентрованого підходу у процесі професійної підготовки лікарів. Проаналізовано комунікативні стилі викладачів дисциплін різних навчальних блоків. Додаються рекомендації для поліпшення навчального процесу при студентоцентрованому підході у медичному ВНЗ.

The results of the study of peculiarities of realization student-centered approach in the professional training of doctors are presented in the article. Communicative style of teachers of the different educational blocks is analyzed. Recommendations to improve the training process in a student-centered approach in medical universities are supplied.
\end{abstract}

Вступ. Актуальність дослідження. Сучасна вища освіта в Україні потребує не тільки удосконалення процесу викладання та передавання знань, а й наголошує на необхідності розвитку критичного мислення, навчання людини пізнання, формування стійкої мотивації, спрямованої на самоосвіту [3]. Здійснюється перехід від змістоцентризму до результатоцентризму [6]. Сучасна педагогіка національного та зарубіжного досвіду пропонує поєднання навчання з вихованням. Суть виховання у ВНЗ полягає в сприянні розвиткові особистості студента і становленню його професійної ідентифікації. Студентоцентрований підхід - тип освітнього процесу, у якому особистість студента й особистість педагога виступають як його суб’ єкти; метою підходу є розвиток особистості учня з урахуванням його ціннісних орієнтацій. Переміщення особистості студента в центр процесу вимагає змін багатьох факторів, у тому числі й типу взаємин “викладач-студент” [4]. Студентоцентроване навчання не зменшує, а змінює роль викладача [5].

( В. М. Лісовий, В. А. Капустник, В. Д. Марковський та ін.
Педагог мусить стати для студента не рольовою функцією, а референтною особистістю. Практична зміна методів і технологій навчання вимагає моніторингу актуального стану різних аспектів навчального процесу. У цьому дослідженні вивчалися деякі аспекти педагогічних комунікацій.

Мета дослідження - виявити особливості реалізації студентоцентрованого підходу в процесі професійної підготовки студентів ХНМУ.

Завдання дослідження: 1) виявити та проаналізувати уявлення студентів про стиль комунікації викладачів дисциплін, що належать до різних навчальних блоків; 2) виявити й проаналізувати комунікативні стилі викладачів; 3) співвіднести уявлення студентів про стилі педагогічного спілкування їхніх викладачів і комунікативні стилі викладачів ХНМУ; 4) розробити рекомендації для поліпшення навчального процесу, грунтуючись на студентоцентрованому підході.

У дослідженні брали участь: 191 студент, з них 89 - 33 курсу й 102 - 35 курсу, які навчаються на медичних і стоматологічному факультетах, а також 
115 викладачів: 21 - з блоку природничо-наукових дисциплін, 70 осіб - з блоку дисциплін лікувальної професійної підготовки та 24 - зі стоматологічної професійної підготовки.

Методики дослідження: 1. Тестова карта комунікативної діяльності, яка розроблена на основі опитувальника А. А. Леонтьєва [2]. Оцінка стилю комунікації викладачів дисциплін різних напрямків студентами проводилася за шкалою Тестової карти комунікативної діяльності: 45-49 балів - дуже високий рівень педагогічної комунікативної компетентності; 35-44 балів - високий рівень; 20-34 - середній рівень; 11-19 балів - низький рівень; 7-10 балів - дуже низький рівень. 3’ясовувалося уявлення студентів про стиль комунікації викладачів різних дисциплін і психологічний клімат на заняттях. 2. Опитувальник “Стиль спілкування педагога”, розроблений І. М. Соколовим, 1987 [7]. Даний опитувальник був задіяний з метою визна- чення комунікативних стилів (“авторитарний”, “демократичний” і “ліберальний” стилі, а також рівень “негативізму”) викладачів дисциплін різних навчальних блоків у навчальних і виховних ситуаціях.

Основна частина. Результати оцінки студентами стилю комунікації викладачів дисциплін різних напрямків із використанням Тестової карти комунікативної діяльності довели, що середні бали за шкалою за оцінками третьокурсників відповідали при викладанні: гуманітарних дисциплін - високій оцінці; природничих дисциплін - високій оцінці, нижній її межі; дисциплін професійної підготовки - задовільній оцінці, верхній межі. Середні бали напрямків за оцінками студентів п’ ятого курсу свідчили, що стиль комунікації викладачів гуманітарних дисциплін, природничо-наукових дисциплін й дисциплін професійної підготовки відповідає високій оцінці. Дані графічно представлені на рисунку 1.

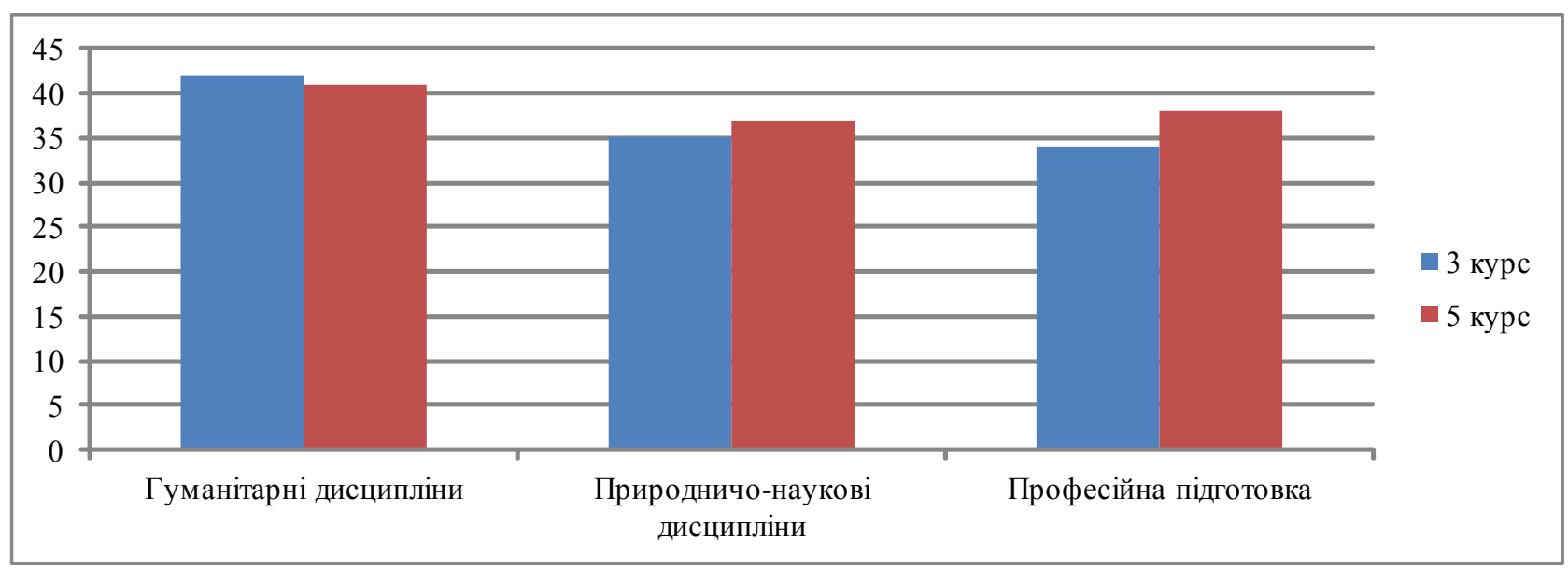

Рис. 1. Порівняльна оцінка уявлень студентів (3 і 5 курсів) про стилі комунікації викладачів різних дисциплін.

Таким чином, студенти 3 і 5 курсів оцінюють стиль викладання гуманітарних та природничонаукових дисциплін як такий, що характеризується невимушеною атмосферою в аудиторії, зацікавленістю учнів. Викладач дотримується плану заняття, але заохочує до висловлення власної думки, пропонує надавати свої рішення. Під час занять використовується гумор, наводяться приклади 3 життя, сторони активно взаємодіють, що сприяє продуктивності навчання.

При цьому стиль викладання дисциплін професійної підготовки оцінюється 5 курсом на такому ж рівні, а 3 курс оцінює комунікативний стиль викладання як задовільний (верхня межа). Контакт 3 аудиторією встановлюється легко, але увага приділяється, в основному, активним учасникам, можливі прояви елементів моделей диференційованої уваги та негнучкого реагування. Стиль викладання фахових дисциплін може оцінюватися трохи нижче, порівняно з дисциплінами інших напрямків, у зв’ язку з крайньою важливістю змістовної частини медичних предметів та більш високими вимогами, що висуваються до студентів.

При загальній високій оцінці рівня викладання студенти 5-го курсу схильні оцінювати викладання природничо-наукових і професійних дисциплін вище, ніж студенти 3-го курсу. Імовірно, сприйняття дисциплін професійної спрямованості може 
змінюватися під впливом власного досвіду студентів і розвитку їхньої професійної компетентності. Можуть змінюватися й критерії, за якими студент оцінює викладача: оцінка міжособистісних стосунків поступається на користь оцінки професійних якостей.
Аналіз комунікативних стилів викладачів природничих, лікувальних і професійних дисциплін у ситуаціях навчання та виховання графічно представлений на рисунках 2 і 3.

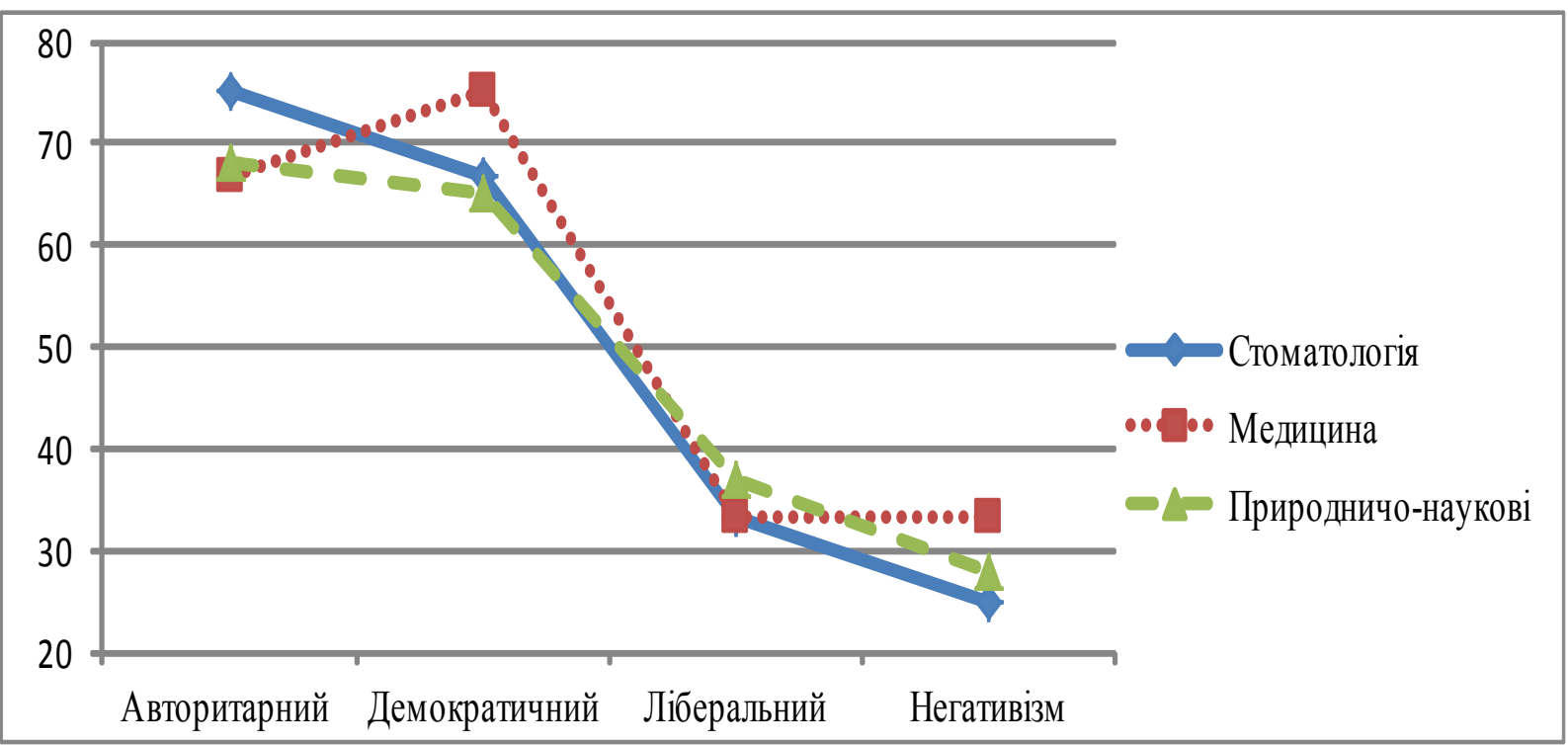

Рис. 2. Порівняння стилів спілкування педагогів у навчальних ситуаціях. Викладачі природничо-наукових, медичних і стоматологічних дисциплін.

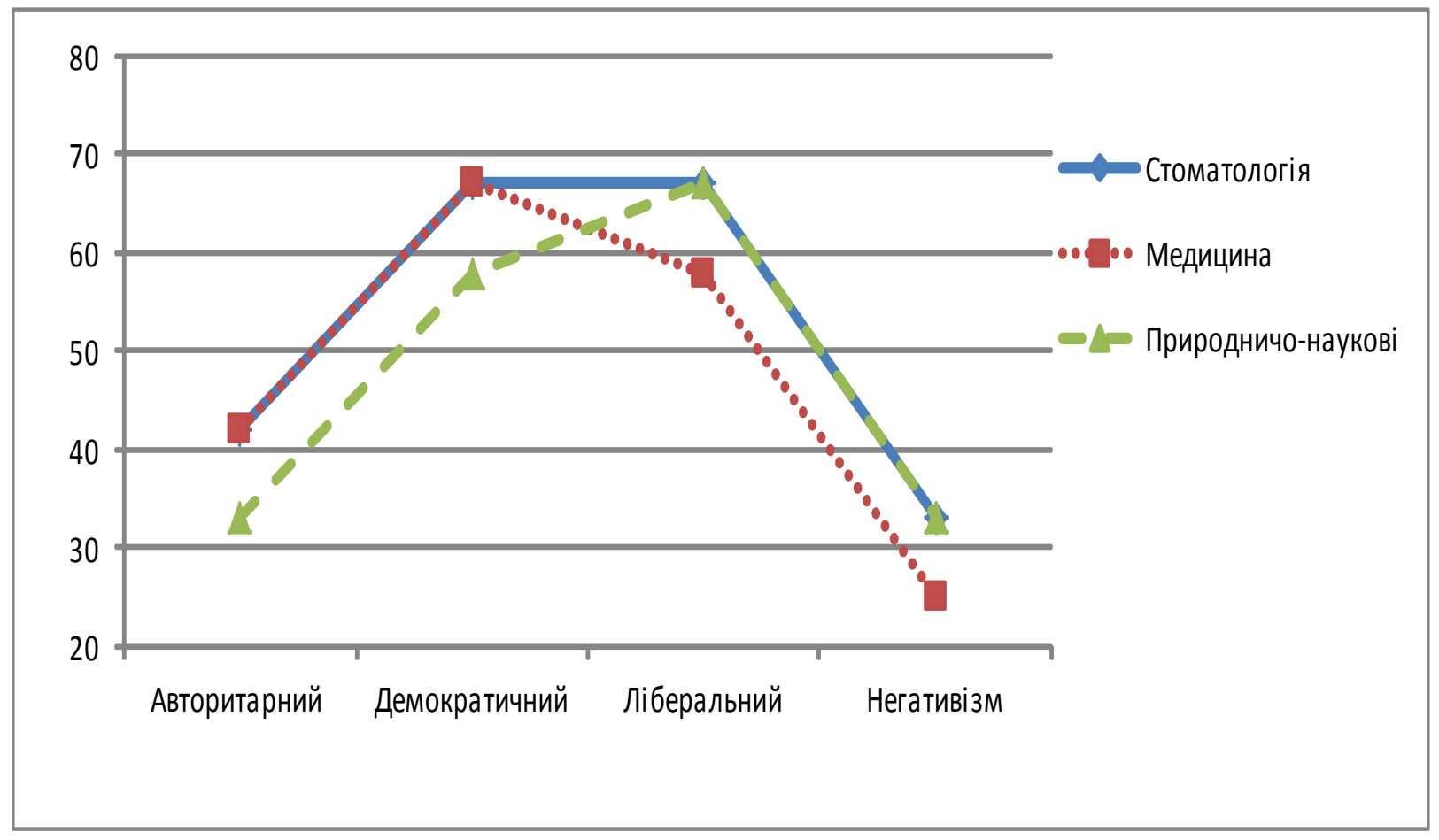

Рис. 3. Порівняння стилів спілкування педагогів у ситуаціях виховання. Викладачі природничих, медичних і стоматологічних дисциплін. 
У навчальних ситуаціях викладачам ХНМУ більше притаманний “змішаний” стиль спілкування зі студентами: авторитарні й демократичні тенденції проявляються майже однаково. 3 одного боку, викладачі змушені концентруватися на великих обсягах інформації та контролі знань, а з іншого - вони намагаються уважно ставитися до учнів. Таким чином, у комунікації поєднується високий рівень вимогливості та поваги до студентів.

Оцінка вибору демократичного стилю свідчить, що різниця між показниками викладачів дисциплін різних груп не дуже істотна: на 1 місці - викладачі професійної підготовки лікувальних факультетів (69,91 \%), на 2 - викладачі стоматологічного факультету (66,83 \%), на 3 - природничо-наукових дисциплін (65,25 \%).

Показники “негативізму” при цьому невисокі (25-33 \%), що говорить про прихильність більшості викладачів до студентів, слабких тенденцій до упередженості та конфліктності, а також, імовірно, про задоволення викладачів своєю роботою.

У виховних ситуаціях викладачам ХНМУ також властивий “змішаний” стиль спілкування, але 3 проявами демократичних і ліберальних тенденцій. Вони працюють з уже досить дорослою аудиторією, відповідальність та ініціатива у виховних ситуаціях передається ними студентам. Питання, чи існує зв’ язок між цими показниками (у ситуації виховання) та розвитком професійної ідентифікації, вимагає подальшого вивчення. Показники “негативізму” також відносно невисокі (17-33 \%).

Припущення, що викладання дисциплін професійної підготовки характеризується суворішими вимогами до студентів, які поєднуються з заохоченням їх самостійності та ініціативності, вимагає подальшого вивчення.

Висновки: 1. Студенти 3 і 5 курсів вважають стиль викладання гуманітарних і природничонаукових дисциплін доволі студентоцентрованим. Активності учнів і творчій роботі приділяється багато часу. Увага до спілкування зі студентом і змістом наукового предмета розподіляється рівною мірою. Дисципліни професійної підготовки оцінюються 5 курсом таким же чином, а 3-курсники визначають стиль їх викладання менше студентоцентрованим; 5 курс оцінює викладання природничо-наукових і професійних дисциплін вище, ніж 3 курс. Згодом сприйняття тих чи інших дисциплін може змінюватися під впливом особистого досвіду студентів і підвищити місце за особистою шкалою переваг.
2. У навчальних ситуаціях викладачам ХНМУ притаманний “авторитарно-демократичний” стиль спілкування зі студентами: з одного боку, викладачі концентруються на інформації та контролі знань, а з іншого - намагаються уважно ставитися до студентів. У комунікації поєднується високий рівень вимог і поваги до студентів. Викладачі прихильні до студентів, тенденції до упередження й конфліктності слабкі. У виховних ситуаціях викладачам властивий “демократичноліберальний” стиль спілкування. Вони припускають, що працюють з уже досить дорослою аудиторією і не завжди усвідомлюють, що відповідальні за виховання і особистісне дорослішання майбутніх медиків. Можливо, це пов'язано 3 недостатньою професійною педагогічною підготовкою більшості викладачів ХНМУ, основна освіта яких медична.

Рекомендації: 1) застосовувати підбір і створення під час навчального процесу ситуацій, у яких вирішуються завдання різного характеру і рівня складності; суб’ єктне залучення студентів у варіативний за змістом, інструментальними характеристиками і підсумковими процедурами навчальний процес; рефлексивна взаємодія викладача та студента; вербалізація сенсу спільних дій у навчальному процесі; упровадження інноваційних форм навчання, самостійних і творчих видів робіт (створення проектів, аналіз ситуацій, участь у конференціях, диспути тощо);

2) для виявлення та обліку індивідуальнопсихологічних особливостей викладачів та їх подальшого навчання організувати регулярну діагностику стилю педагогічного спілкування, внести до тематичних планів перепідготовки та підвищення кваліфікації викладачів вивчення питань змісту та структури стилю педагогічного спілкування. При прийнятті викладачів до ВНЗ організовувати їх зустрічі з керівництвом і методистами, призначати педагогам кураторів з числа досвідчених викладачів з метою ознайомлення з особливостями педагогічної взаємодії;

3) проводити психологічну роботу, основану на принципах клієнт-центрованого підходу із застосуванням технік арт-терапії для формування у викладачів таких психологічних якостей і здібностей, як: здатність до емпатії і розуміння людей; гнучкість, оперативно-творче мислення; уміння використовувати зворотний зв’язок у спілкуванні; здатність управляти собою; уміння прогно- 
зувати можливі педагогічні ситуації; виявлення вербальних здібностей; здатність до педагогічної імпровізації;

4) проведення психологічної роботи з групами студентів, для розкриття їх творчого потенціалу та

\section{Список літератури}

1. Бех І. Д. Концептуальна модель я-центрованості у вихованні та духовному розвитку особистості / І. Д. Бех // Духовність особистості: методологія, теорія і практика. - 2015. - № 1 (64). - С. 4-27.

2. Психологические тесты. Т. 1 / А. А. Карелин (ред.). - М. : Гуманит. изд. центр ВЛАДОС, 2002. T. $1 .-312$ c.

3. Киш О. М. Студенто-центроване навчання як складова нової парадигми освіти / О. М. Киш // Наукові пошуки: збірник наукових праць молодих учених. Вип. 9 / за ред. проф. А. А. Сбруєвої. - Суми : Вид-во СумДПУ імені А. С. Макаренка, 2013. - С. 34-40.

4. Кіпень В. П. Нова філософія освіти та моделі діяльності викладачів вузів [Електронний ресурс] / В. П. Кіпень. нормалізації психологічного стану. Проведення регулярних опитувань про оцінку якості викладання, враження від навчального процесу і його можливих змін допоможуть виявити моменти, які потребують подальшого удосконалення.

5. Носко И. В. Студентоцентрированное образование / И. В. Носко // Вектор науки ТГУ. - Владивосток, 2011. - № 1(4). - C. 126-138.

6. Сбруєва А. А. Теоретичні та методичні засади студенто-центрованої парадигми навчання у контексті реалізації болонських реформ / А. А. Сбруєва // Розвиток інтелектуальних умінь творчих здібностей учнів та студентів у процесі навчання дисциплін природничоматематичного циклу “ІТМ*Плюс - 2014” : матеріали міжнар. дистанційної наук.-метод. конф. : у 3-х ч. Суми : Мрія, 2014. - Ч. 1. - С. 68-70.

7. Фоминова А. Н. Педагогическая психология : учебное пособие / А. Н. Фоминова, Т. Л. Шабанова. - М. : ФЛИНТА, 2016. - 380 с. 